\title{
Students' Perceptions of the Use of ICT in a Higher Education Teaching and Learning Context: The Case of a South African University
}

\author{
Dr. Alfred H. Makura \\ Central University of Technology, Department of Postgraduate Studies: Education, \\ P. Bag X20539, Bloemfontein, South Africa \\ Email:amakura@cut.ac.za
}

\author{
Doi:10.5901/mjss.2014.v5n11p43
}

\begin{abstract}
The aim of this paper was to investigate students' perceptions of ICT usage by staff and students at a South African University. A researcher crafted questionnaire-interview (Questaview) was anonymously administered to a randomly selected group of fifty students to enlist their views on the extent to which they and academic staff utilise ICT during learning and teaching. There were a total of 44 usable returns. Data were analysed thematically after interrogating the responses through coding. Results showed that students perceived 'technology for learning' to mean a computer. They were satisfied with its use and functionality since commencing their studies. Students also reported that most lecturers do not use ICT for teaching. Students perceived ICT particularly the computer, as impacting positively on their academic success, academic access and other curricular issues. We concluded that despite the challenges such as an underutilisation of other ICT's by lecturers, the students perceived ICT in their learning as useful. Students' perceptions in the use of ICT by themselves and their lecturers did not differ much. Moreover, they suggested ways in which lecturers could use more ICT for teaching and learning purposes. On this basis, the paper suggests that universities should sustain their ICT e-learning programmes and training by channelling financial support if student academic performance and quality are to be enhanced. The positive impact of such initiatives makes a strong case for massive investment in e-learning programmes especially among academic staff.
\end{abstract}

Keywords: higher education, e-learning, academics, perceptions, South Africa

\section{Introduction}

Information and Communications Technology (ICT) are a diverse set of technological tools and resources used for creating, storing, managing and communicating information, and to support teaching and learning and research activities (Vajargah, Jahani \& Azadmanesh, 2010). The use of the Internet and other information and communication technologies (ICTS) in higher education locally and globally has been phenomenal. This is predicated on the rapidly changing environmental dynamics, globalisation, demand for ICT and life-long learning as well as competition among private and public institutions (Collis \& van Der Wende 2002; James 2008). This rapid migration into the digital age calls for the adoption of ICT by higher educational institutions due to its potential effect on educational, social and economic dynamics. The educational benefits of ICTs in teaching and learning are well catalogued (Tok \& Sora 2013; Yunus, Nordin, Salehi, Embi \& Salehi 2013; Mullamaa 2010; Pretorius, Steyn \& Johnson 2012; James 2008.....). Such benefits include their impact on catalysing teaching practice thoughts; language acquisition; motivating learners; enhancing students' academic performance and enhancing pedagogy (Jaffer, Ng'ambi \& Czerniewicz 2007). Research shows that despite the benefits, higher education institutions have been rather slow in tapping on ICT potentiality particularly for teaching and learning purposes. South Africa is no exception to these notions.

\subsection{ICT uptake in higher education}

The uptake of ICT in higher education stem from a strong institutional policy and support base. Cross and Adam (2007) opined that such policy initiatives and strategies were critical to national, social and economic development goals. Using the South African higher education landscape, Cross and Adam (2007) argued that despite ICT usage having increased, most institutions did not have comprehensive institutional visions or strategies on ICT use. The policies are part of the broader institutional imperatives and the intents and purposes of vary from institution to institution. A cursory look at a few South African universities' strategic plans seem to buttress these assertions. For instance, the University of Free State's Strategic plan (2012) Information Technology policy puts more emphasis on students' performance and lecturer 
capabilities in ICT usage. Their plan is to "...take a long-term view, to migrate from occasional access to 'always-on' status for 30000 students over the next five years" (UFS Strategic plan 2012:48). The University of Fort Hare likewise, confirmed in its policy documents (UFH ICT policy document) that ICT use within South Africa has been growing rapidly for more than a decade. The institution's Strategic Plan advocates the promotion of Technology-enhanced Learning (TeL) albeit, as one of the key objectives within the strategic goal of teaching and learning, research and community engagement excellence (UFH Strategic Plan 2012). The university of Venda Strategic plan cites ICT as critical success factor 'in support of the university's core business' (Univen Strategic Plan 2012:46). The university in its SWOT analysis (Univen Strategic Plan 2012:13) boasts of academics with laptops, functional modern hardware and software, and students with internet access but inadequate computer facilities and internet capacity.

The ICT models that the cited institutions seem to have adopted in embracing ICT resonate and have semblance with models suggested by Mhlanga (2006). These are the supplemental, replacement, emporium and the buffet models. The first three cited models seem to be the dominant ones in most institutions. These models retain the traditional teaching and learning approaches with gradual supplementation with ICT interactive approaches. Most South African higher education strategic plans advocate ICT access and use while retaining the human element through the lecturer's role. The buffet model advocates a radical shift towards total adoption of ICT grounded teaching methodologies that take into account individual students' learning styles. This strategy has benefits for the student. Some of the benefits in ICT use of in education are that it help improve memory retention, increase motivation and understanding (Dede, 1998), promote collaborative learning, and problem solving activities (Forcheri \& Molfino, 2000). Despite these noble goals and benefits, Oliver (2002) has for instance shown that the education field has not been faster in its adoption of ICTs compared to fields such as medicine, tourism, engineering, law and others. Several reasons have been advanced for this uncanny impact (see for instance Oliver 2002; Collis 2002; Kirkup \& Kirkwood 2007; Collis \& van Der Wende 2002; Stensaker, Maassen, Borgan, Oftebro \& Karseth 2007; James 2008).

Despite is perceived and proven benefit, ICT uptake by higher education institutions for teaching and learning purposes has been below par. in the case of South Africa Jaffer, Ng'ambi and Czerniewicz (2007) have opined that the potential use of ICTs in addressing teaching and learning needs is difficult to authenticate. Such a development has the potential of creating some an anxiety among the primary consumers of such technologies, the student. In their South African study Jaffer, Ng'ambi and Czerniewicz (2007) suggested that ICT use was a useful strategy in addressing persistent teaching and learning challenges. Such challenges according to the authors encompassed students' diversity, the deep rooted stemming from the racially segregated apartheid legacy and large classes. These bred academic under preparedness and compounded linguistic challenges in a multilingual context. A Zimbabwean study by Chitiyo (2006) attributed the underutilisation of ICT usage by academics to weird conceptualisation and integration of IT. The academics viewed ICT as being synonymous with hardware and akin to audio-visual aids. Moreover the academics proficiencies in computers for instance was at the basic level. Institutional financial and policy support were reportedly lacking as most academics struggled to access the appropriate technological tools. A Thai study (James 2008) noted that fewer academics utilised ICTs suggesting that it was less effective that the traditional pedagogic approaches.

The uptake of ICT in the African context is recognised as an imperative. The challenges alluded to earlier on, could be addressed if ICTs are integrated into the teaching -learning milieu. James (2008) demonstrated that universities need to account for public funds and spinoffs derived from embracing ICTs. He suggested the infusion of e-learning into traditional educational offerings through blended learning and creation of virtual universities. Bladergroen et al (2013) opined that the success in ICT usage lay in training pre-service and in-service personnel. The benefits will then cascade to the end user.

\subsection{Statement of problem}

Higher education institutions have responded slowly to ICT/TeL awareness and usage. Fewer research studies have ventured into investigating students' perceptions of the use of ICTs by academics in South African higher education institutions. This is despite global evidence that points to lower ICT usage by few academics. That fewer academics use few available ICTs such as WebCT and Blackboard for teaching and learning purposes is a cause for concern for higher education institutions.

\subsection{Purpose of study}

This study endeavours to investigate students' perceptions of their use of ICT and by academic staff at a South African conventional university. A secondary aim was to establish if the students differed in their perception on the use of ICT at 
the studied university.

\subsection{Research question}

What is the nature and extent of ICT use by academics at an institution of higher learning as perceived by students?

\section{Methodology}

\subsection{Design}

The study adopted the interpretive research approach. The intention was to tap into the students' experiences or encounters with ICT at the university in question. To this end, a case study methodology design was used.

\subsection{Instrument:}

Data for the study were collected through a researcher designed questionnaire-interview guide (questaview). This instrument act both as a questionnaire and an interview in that the solicited data that can be developed into themes or numerals.

\subsection{Sample}

Fifty respondents were initially targeted. The instrument was given to students that visited the academic development centre of the studied university. Respondents consented to responding to the instrument. The data collection activity lasted two weeks after which 44 usable instruments' data were analysed. These were completed by 21 first year students; 14 in year 2; Five (5) in year three and four (4) in their fourth year.

\section{Results}

\subsection{The types of technology used by students at the university}

The first question on the instruments requested the students to list the nature of ICT they used mainly at the institution. The following technologies were cited: computer, Internet, Cellphone, projector and photocopying machines. Other respondents listed the library as a source for 'technology' such as textbooks and journals. A respondent cited the university's computer centre that is housed in main hall. An equally perplexing response was from a respondent that viewed technology as 'studying alone or in group/consultations'. When asked further on what technologies they 'had acquired since arriving at the university' the respondents listed the same gargets alluded to earlier on. One respondent however said he/she had acquired 'none'.

\subsection{Technology used by lecturers as perceived by students}

When asked to list the types of technology used by their lecturers, the respondents listed the following gargets: Projector, overhead projector, computer, laptop and microscope. Some of the respondents said that their lecturers used 'computer databank', PowerPoint presentation, slides, Emails and Blackboard. Of course, these software use the laptop or desktop hardware. The respondents saw these as part of technology.

\subsection{Technologies available at the University}

The respondents listed the same gadgets they had listed in an earlier question. The following technologies were perceived as being available at the institution: computer, projector or overhead projector, Internet, microscope and photocopying machines. The library featured again as part of technology. Regarding the library a respondent listed OPAC (Online Public Access Catalogue) and textbooks. 


\subsection{How ICT should be used by lecturers at university}

A critical question to the study related to students' perceptions regarding how ICT should be utilized at institutional level. One of the respondents said that students needed "More computers for research". Another one echoed similar sentiments by submitting "More computer labs". A few respondents expected lecturers to 'email lecture notes' to them. An indifferent opinion stemmed from a respondent that said that the university needed to "Maintain status quo "my degree does not require much use of technology...". The projector was also listed as a useful tool. This probably was the overhead or data projector. One of the respondents suggested that the university needed "more working computers and photocopying machines". This probably stemmed from an observation that some of the technology were not being serviced. An interesting suggestion came from a respondent who proposed that lecturers should work through student assistants involved in the university's academic support programmes (Supplemental Instructional Leaders as they were referred to). These student assistants were said to use technology more frequently than the lecturers. A respondent said that the student assistants were more "active and motivated" them.

\section{Discussion}

As revealed in the preceding findings, it is noted that students used a variety of ICT gargets in their higher education context. These are the generic gadgets such as projectors, photocopying machines and computers. The respondents did not cite the latest teaching and learning gadgets such as smart boards and smart phones. These and related software are useful and user friendly $21^{\text {st }}$ century teaching-learning gadgets that lecturers particularly, overlook in teaching and learning scenarios. Regarding ICT use by lecturers during teaching and learning, the respondents cited similar gargets to those that they claimed to use. The Cell phone was however not cited. This shows that some lecturers in do not utilise this handy gadget for teaching and learning purposes in universities. This pedagogic unfamiliarity of academics with latest technology buttress the assertion that most academics do not fully utilise ICT during teaching and learning. Vajargah, Jahani and Azadmanesh (2010) were correct when then argued that ICT literacy was imperative in a higher education context. The low or poor usage of ICT usage by academics has the potential of demotivating students. Torenbeek, Jansen and Hofmman (2011) argued that poor first-year experiences increased withdrawal. Such a development emanated from a misfit between students' prior experiences with ICT and a university environment devoid of such technology. Despite the low usage of ICT by lecturers, the students found solace in the availability of some ICT within the institution.

As data for this study show, the institution studied appears not to have invested a lot in ICT for teaching related areas. The ICT mentioned by the students is the common or generic ones characterizing most South African higher education institutions. Thus there is a discrepancy between policy enunciation and facts on the ground. The institution studied, just like other South African universities have noble ICT policies but more need to be done to invest into latest pedagogically inclined ICT. Mhlanga (2006) advocated the implementation of the Buffet model or approach wherein institutions should embrace ICT dominated pedagogies.

\section{Conclusion}

Central in this study was establishing the perceptions of university students regarding ICT availability and the pedagogical practices of academics relating to ICT usage in a South African university. Despite the challenges such as an underutilisation of other ICT's by lecturers, the students perceived ICT in their learning as useful. Students' perceptions in the use of ICT by themselves and their lecturers did not differ much. Results showed that students acknowledged the existence within the institution, of traditional ICT teaching gargets such as computers, projectors, microscopes and photocopying machines. A few respondents disclosed that their lecturers used 'computer databank', PowerPoint presentation, slides, Emails and Blackboard for teaching purposes. It was these gadgets that lecturers tended to use most during their teaching and learning activities. Respondents did not cite the Cell phone as a useful teaching aid since their lecturers did not use it. The library was perceived as part of ICT probably because it harboured ICT related gargets. The paper concluded that students yearned for more functional gargets and ICT venues within the institution. A compelling finding is the suggestion that lectures needed to work through student assistants in their quest to diversify ICT usage. 


\section{Recommendations}

It is imperative that universities invest massively in ICT for teaching and learning. Research show that those institutions that invest heavily in ICT have better students' academic performance and throughput rates. There is need for schools to expose students to more technology for learning prior to entry into university. This has the advantage of reducing withdrawal but increasing their motivation, belonging, and concept mastery. There is also a need to capacitate academics technologically through increasing skills that enhance technology use in learning and teaching. Institutions should promulgate policies that compel academics to utilize ICT for teaching and learning. For instance the promotion process could be tied to ICT use during lectures and in assessment. South African universities are lucky in that they receive state funding in form of the Teaching and Learning Grant. These institutions should of necessity utilise the bulk of this grant in skills development for lecturers as well as equipping lecture halls with latest technology for teaching. Lastly, in the South African context, centres of teaching and learning excellence (Academic Development Centres) should spearhead ICT usage by academics and ICT training and technology for learning. Such efforts should not be left to the discretion of individual lecturers' efforts. As such, the paper suggest that universities sustain their ICT and e-learning programmes and training by channelling financial support if student academic performance and quality are to be enhanced.

\section{References}

Bladergroen, M., Chigona, W., Bytheway, A., Dumas, C., Cox, S \& Van Zyl, I. 2013. The dynamics of offering ICT training to pre-service and In-service teachers in a South African context.

Chitiyo, R. 2006. Integration of instructional technology by university lecturers in secondary school teacher education programmes in Zimbabwe: An exploratory study. A Doctoral thesis submitted to the college of education: Georgia State University accessed on 09 May 2014 from hptt://www.search.proquest.com/docview/

Cross, M \& Adam, F. 2007. ICT policies and strategies in Higher Education in South Africa: national and institutional pathways. Higher Education Policy, 20 (1), 73-95

Dede, C. (Ed.)(1998). Learning with technology. Alexandria, VA: ASCD.

Forcheri, P. \& Molfino, M.T. (2000). ICT as a tool for learning to learn. In: Watson, DM and Downes, T (Eds). Communications and networking in Education. Boston: Kluwer Academic, 175-184.

Jaffer, S., Ng'ambi, D. \& Czerniewicz, L. 2007. The role of ICTs in higher education in South Africa: One strategy for addressing teaching and learning challenges. International Journal of Education and Development using Information and Communication,3 (4), 131142.

James, PTJ. 2008. Academic staff perceptions of ICT and e-learning: A Thai HE case study. The Turkish online Journal of Educational Technology, 7(4), 36-45.

Kirkup G. \& Kirkwood, A. 2007. Information and communications Technologies (ICT) in higher education teaching- a tale of gradualism rather than revolution. Learning, Media and Technology, 30 (2), 185-199.

Mhlanga, F.S. 2006. A developing country's Information and Communication Technology infrastructure in perspective: A vision for the $21^{\text {st }}$ century. Journal of Integrated Design and Process Science, 10 (1), 71-78.

Mullamaa, K. 2010. 'ICT in language learning-benefits and methodological implications', International Education Studies, 3(1), 38-44.

Oliver, R. (2002). The role of ICT in higher education for the 21st century: ICT a change agent for education. Retrieved on 12 February 2103 from http://bhs-ict.pbworks.com/f/role\%25200f2520ict.pdf

Pretorius, HW., Steyn, AA \& Johnson, RD. 2012. Pair teaching of ICT in higher education: a multi-perspective reflection, Research in Higher Education Journal, 17, 1-12.

Rambe, P. \& Nel, L. 2013. Students' perceptions on the usefulness of educational technologies at a South African university. Paper presented at the 411-XVI. Retrieved on 09 May 2014 from http://search.proquest.com/docview/1467836016?accountid=15731

Stensaker, B., Maassen, P., Borgan, M., Oftebro, M. \& Karseth, B. 2007. Use, updating and integration of ICT in higher education: Linking purpose, people and pedagogy. Higher Education, 54: 417-433.

Tok, BR \& Sora M. 2013. Perspective of emerging integrating technology (ICT) in learning and teaching. International Journal of Information and Education Technology, 3 (2) 282-285.

Torenbeek, M., Jansen, EPWA \& Hofman, WHA (2011). Predicting first-year achievement by pedagogy and skill development in the first weeks at university. Teaching in Higher Education, 16 (6), 655-668.

University of the Free State (2012). Strategic plan 2012-2016. Retrieved 11 May 2014 from http://www.ufs.ac.za/dl/userfiles /Documents/00001/931.pdf

University of Venda (2012). Univen Strategic Plan 2012. Retrieved on 11 May 2014 from http://www.univen.ac.za/index.php ?Entity=Strategic Plan

University of Fort Hare (2012). Strategic plan: 2012-2016. Alice: UFH Institutional Repository

Vajargah KF, Jahani, S \& Azadmanesh, N. 2010. Application of ICTs in teaching and learning at university level: The case of Shahid Beheshti University. The Turkish Online Journal of Educational Technology, 9 (2), 33-39.

Yunus, M.M., Nordin, N., Salehi, H., Embi MA \& Salehi Z. 2013. The use of Information Technology (ICT) in teaching ESL writing skills. English Language Teaching, 6 (7), 1-8. 
